\title{
ВАЛЕРИЙ СТЕПАНОВИЧ ШИРИНСКИЙ (К 70-ЛЕТИЮ СО ДНЯ РОЖДЕНИЯ)
}

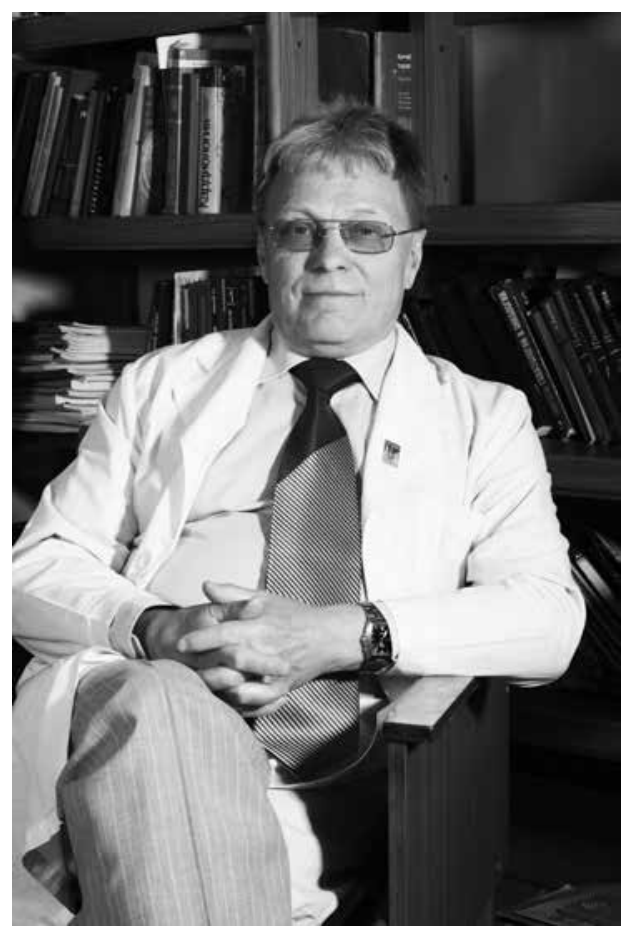

18 июня 2014 года исполняется 70 лет со дня рожденияВалерия Степановича Ширинского - профессора, доктора медицинских наук, заслуженного врача России, врача высшей категории, академика МАН ВШ, заведующего лабораторией клинической иммунофармакологии ФГБУ «НИИКИ» CO PAMH.

Ширинский В.С. родился в городе Новосибирске, в 1968 году окончил Новосибирский государственный медицинский институт,поступил в аспирантуру при кафедре факультетской терапии НГМУ, успешно сочетая интенсивную научную деятельность с клинической работой, ночными дежурствами и работой на «Скорой помощи», в настоящее время является руководителем лаборатории клинической иммунофармакологии НИИ клинической иммунологии СО РАМН.

В 1976 году в г. Ярославле В.С. Ширинский защитил кандидатскую диссертацию на тему «К изучению гиперчувствительности замедленного типа у больных ревматоидным артритом», 1976, а в 1986 г. в Институте ревматологии РАМН, г. Москва - докторскую диссертацию на тему «Иммунорегуляторные нарушения при различных клинических вариантах ревматоидного артрита».

B.C. Ширинским открыты новые закономерности нарушения функции регуляторных Т-лимфоцитов при органоспецифических аутоиммунных заболеваниях, их роли в процессах хронизации воспаления и склерогенеза, влияния стрессогенных воздействий на формирование вторичных иммунодефицитов (ВИД). Им впервые разработаны фундаментальные основы взаимодействия иммунной и вегетативной нервной системы в норме и при иммунопатологических состояниях человека, показана роль различных отделов вегетативной нервной системы в развитии ВИД при хроническом бронхите, рецидивирующей герпетической инфекции.

В.С. Ширинский является признанным специалистом в ревматологии, клинической иммунологии и аллергологии. Широчайшая эрудиция, глубокое клиническое мышление и колоссальный опыт делает для него подвластным секреты решения самых трудных и запутанныхклинических ситуаций, связанных с диагностикой тяжелых хронических заболеваний и выбором адекватного лечения. Неслучайно у профессора В.С. Ширинского консультируются пациенты разного профиля не только из Новосибирска, но и из области и отдаленных городов Сибири.

Многогранность его лечебной деятельности в области диагностики, профилактики и лечения аутоиммунных и аллергических заболеваний, вторичных иммунодефицитов плодотворно сочетает- 
ся с научными исследованиями по вопросам иммунопатогенеза и лечения ревматоидного артрита, системной красной волчанки, остеоартрита, вторичных иммунодефицитов при хронических воспалительных поражениях бронхолегочного аппарата, ЛОР-органов, инфекционных дерматитах и т. д., аллергических заболеваниях.

В.С. Ширинским обобщен многолетний опыт наблюдения за больными ВИД, который послужил основой для разработки оригинальной этиопатогенетической классификации ВИД, которая широко используется на практике.

В.С. Ширинский известен как специалист в области иммунофармакологии. Им предложен оригинальный многоэтапный метод выявления иммуноактивных свойств биологически активных веществ invitro, показаны иммуноторопные свойства ряда биологически активных соединений (производные алканкарбоновых кислот, германия, биофлаваноидов и др.).

В последние годы научные интересы В.С. Ширинского связаны с изучением особенностей иммунопатогенеза ревматоидного артрита и атеросклероза, разработки новых подходов к многоцелевой терапии этих заболеваний на основе использования агонистов PPAR и ингибиторов 3-гидрокси-3 метилглутарилкоэнзим А редуктазы. Результаты ряда исследований позволили В.С. Ширинскому впервые сформулировать концепцию узловой (hub) терапии синтропных коморбидных заболеваний, связанную с модуляцией мишеней, выполняющих ключевую роль в регуляции воспаления, липидного обмена, свертывания крови и т.д.

Под руководством В.С. Ширинского создана школа высококвалифицированных специалистов в области аллергологии и иммунологии, ревматологии, иммунофармакологии.

В.С. Ширинским опубликовано свыше 360 научных работ, одна монография, он автор 12 изобретений, под его руководством защищено 14 кандидатских диссертаций и одна докторская диссертация.

Блестящие организаторские способности В.С. Ширинского проявились в организации муниципального диспансера клинической иммунологии, становлении и развитии клиники иммунопатологии ФГБУ «НИИКИ» СО РАМН, консультантом которой он является.

Много внимания и сил В.С. Ширинский уделяет педагогической работе. Под его руководством в Новосибирской государственной медицинской академии в 1989 году организован курс клинической иммунологии, в последующем кафедра, профессором которой он был до недавнего времени.

В.С. Ширинским разработаны методики преподавания аллергологии и иммунологии для студентов, слушателей ФУВ, которые обобщили его многолетний опыт клинициста и ученого, издан ряд методических пособий, разработаны оригинальные обучающие и контрольные тестовые задания.

Много времени В.С. Ширинский уделяет общественной работе. Он является членом правления РНОИ, Общества ревматологов Новосибирской области, редколлегии журнала «Цитокины и воспаление».

В.С. Ширинский награжден значком «Отличник здравоохранения СССР», удостоен звания «Заслуженный врач РФ».

В эти юбилейные дни редакция журнала «Медицинская иммунология» присоединяется к многочисленным поздравлениям в адрес профессора В.С. Ширинского и желает ему творческого долголетия и активной работы на благо развития иммунологии и ревматологии. 